\title{
The evaluation of the oxidative stress index of reproductive tissues and serum thiol/disulphide homeostasis during estrous cycle in bitches
}

\author{
Duygu BAKİ ACAR ${ }^{1, a, \bowtie}$, Mürşide Ayşe DEMİREL ${ }^{2, b}$, Saadet Özen DİZAKAR AKARCA ${ }^{3, c}$, \\ Muhammed Kürşad BİRDANE ${ }^{1, d}$ \\ ${ }^{1}$ Afyon Kocatepe University, Faculty of Veterinary Medicine, Department of Obstetrics and Gynecology, Afyonkarahisar; \\ ${ }^{2}$ Gazi University, Faculty of Pharmacy, Department of Pharmacology, Laboratory Animal Care and Research Unit, Ankara; \\ ${ }^{3}$ Gazi University, Faculty of Medicine, Department of Histology and Embriology, Ankara, Turkey.

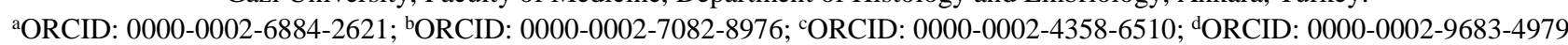 \\ Corresponding author: dbakiacar@gmail.com \\ Received date: 09.08 .2019 - Accepted date: 28.10 .2019

\begin{abstract}
The aim of this study was firstly to determine the relationship between estrous cycle and oxidative stress in reproductive tissues in bitches. This research was performed in twenty-nine healthy bitches from different breeds and of varied ages (the range was 2-5 years) that were brought to the clinic for routine ovariohysterectomy. The stages of estrous cycle were detected using by vaginal cytology, blood progesterone level and histological findings. Ovarian, oviduct and uterine tissues were taken into Eppendorf tubes for oxidative stress index and stored at $-80^{\circ} \mathrm{C}$ until analyses. Also, another part of these tissues were fixed in $10 \%$ formalin solution. There were no significant differences $(\mathrm{P}>0.05)$ among total antioxidant status (TAS), total oxidant status (TOS) and oxidative stress index (OSI) values in the reproductive tissues in concerning estrous cycle stages. However, there were remarkable correlations between oxidative stress parameters and reproductive tissues in different estrus stages in bitches. In conclusion, the physiological values of TAS and TOS concentration, and OSI in the ovarian, oviduct and uterine tissues during estrous cycle were firstly defined in this article. The serum thiol/disulphide homeostasis was also determined in the estrous cycle of bitches. We have found that there are remarkable variations of oxidative stress balance in the ovary, oviduct and uterus concurrently, during estrous cycle in the bitches. Besides, significant correlations between oxidative stress parameters and estrous cycle stages in the reproductive tissues were observed in the present study.
\end{abstract}

Keywords: Bitch, estrous cycle, oxidative stress index, progesterone, thiol/disulphide.

\section{Köpeklerde östrus siklusu boyunca reprodüktif dokularda oksidatif stres indeksi ve serum tiyol/disülfit homestazının değerlendirilmesi}

Özet: Bu çalışmada, köpeklerde östrus siklusu ile reprodüktif organlardaki oksidatif stres arasındaki ilişkinin ilk olarak ortaya konulması amaçlandı. Bu araştırma, rutin ovaryohisterektomi için kliniğe getirilen farklı ırklardan ve değişik yaşlardan (2-5 yıl arasında) sağlıklı yirmi dokuz köpekte gerçekleştirildi. Östrus siklusunun evreleri vajinal sitoloji, kan progesteron seviyesi ve histolojik bulgular ile tespit edildi. Ovaryum, ovidukt ve uterus dokuları, oksidatif stres indeksinin belirlenmesi için Eppendorf tüplerine alındı ve analiz edilene kadar $-80^{\circ} \mathrm{C}$ de saklandı. Ayrıca, bu dokuların diğer bir kısmı $\% 10$ formalinde fikse edildi. Reprodüktif organlardaki total antioksidan durum (TAS), total oksidan durum (TOS) ve oksidatif stres indeksi (OSI) düzeylerinde östrus siklusu evreleri bakımından istatistiksel bir fark bulunmadı $(\mathrm{P}>0,05)$. Ancak östrus siklusunun farklı evrelerinde oksidatif stres parametreleri ile reprodüktif dokular arasında dikkat çekici korelasyonlar belirlendi. Sonuç olarak, bu araştırma ile köpeklerde östrus siklusu boyunca ovaryum, ovidukt ve uterus dokusundaki TAS, TOS ve OSI'nin fizyolojik değerleri ilk kez ortaya konuldu. Ayrıca köpeklerde östrus siklusunun evrelerine göre serum thiol/disülfit homeostazisi de belirlendi. Bununla birlikte, reprodüktif dokulardaki oksidatif stres parametreleri ile östrus siklusunun evreleri arasında önemli korelasyonların olduğu gözlendi.

Anahtar sözcükler: Dişi köpek, oksidatif stres indeksi, östrus siklusu, progesteron, tiyol/disülfit.

\section{Introduction}

Domestic canids are typically classified as monoestrus, and have three estrous cycle every two years. However, in domestic bitches, most females display two estrous cycle in one year. The estrous cycle of bitches is much longer than those of other animals, and consists of proestrus, estrus, diestrus and anestrus stages (22). Endocrine mechanism of canine cycle differs from other mammalian species; ovulation occurs 2-3 days after LH surge at the end of proestrus or at the beginning of estrus 
phase. The bitch becomes receptive to the male in estrus phase during rising progesterone levels. Unlike those of other mammalians, estrus stage proceeds under the influence of progesterone hormone in bitches $(2,5)$. The changes in the reproductive organs in relation with steroids and gonadotrophins are ever-repeating process. During estrous cycle, preantral follicles grow, granulosa cells in the antral follicles transform into the luteal cells, ovulation occurs, and corpora lutea develops and then regress in the ovary of bitches. In addition to this, proliferative, regressive, and apoptotic changes occur in the endometrium of uterine tissue and vagina synchronously with ovarian changes $(21,28)$.

Oxidative stress is defined as a result of an increased number of lipid and protein oxidation products, and decreased number of antioxidants. Under normal conditions, pro-oxidants and antioxidants remain in balance in aerobic cells (1). The oxidative stress balance not only plays a crucial role for healthy body, but it is essential also for reproductive system physiology. It is well known that the reproductive physiology is a continuous process with follicular growth, preovulatory luteinizing hormone (LH) surge, oocyte maturation, ovulation, formation of corpus luteum, steroidogenesis, luteolysis, endometrial proliferation and regression, fertilization, embryonic growth, and pregnancy (1, 18, 20). Reactive oxygen species (ROS) are markers of oxidative stress, and ROS are both by-products and influencers of normal reproductive metabolism, especially for steroidogenic cells (24). However, in some cases ROS production may be increase, and enzymatic or nonenzymatic antioxidants such as superoxide dismutase, catalase, vitamin E, vitamin C, selenium, zinc, glutathione fail to reduce ROS excess; then, oxidative stress causes damage in cells and tissues. In female reproduction, insufficient antioxidant defense mechanism and/or excessive production of ROS may play an important role on infertility, repeat breeding, inadequacy of oocyte maturation or embryo development, cystic ovarian diseases, endometriosis, preeclampsia, abortions (13-15, 19). The levels of antioxidant and oxidant components influence oxidative balance in the aerobic cells. Individual metabolites of ROS, which are superoxide, hydrogen peroxide and hydroxyl, may not necessarily reflect the whole condition of oxidative stress in the organism. Therefore, the measurement of TAS, TOS and the calculation of OSI reflect the relation between ROS formation and antioxidant activity (9).

Dynamic thiol/disulphide homeostasis plays a critical role in antioxidant protection similarly to enzymatic and non-enzymatic antioxidants both in physiologic and pathological conditions such as antioxidant protection, detoxification, signal transduction, apoptosis, regulation of enzymatic activity and transcription factors and cellular signaling mechanisms. Cysteine, cysteinylglycine, glutathione, homocysteine, $\gamma$ glutamylcysteine, and $\beta$-mercaptoethanol are most known thiol compounds $(4,6,10)$. Some of these thiol compounds such as cysteine, cysteamine and $\beta$ mercaptoethanol are known to improve oocyte maturation in vitro and promote late embryonic development $(12,25)$. In the light of these scientific findings, the aim of the present study was to firstly evaluate TAS, TOS levels of the ovarian, oviduct and uterine tissues and OSI, and serum thiol/disulphide homeostasis in bitches during estrous cycle.

\section{Material and Methods}

The present study was maintained in accordance with the directions of Guide for the Care and Use of Animal in Research (AKUHADYEK-24-18). This research was performed in 29 healthy bitches from different breeds and of varied ages (between 2 and 5 years) that were brought to the Afyon Kocatepe University Veterinary Health Application and Research Center for routine ovariohysterectomy. Research material was formed obtained blood, ovarian, oviduct and uterine tissues from these bitches. For this purpose, general clinical examination of bitches was performed. The stages of estrous cycle were determined using by vaginal cytology, serum progesterone level and histological findings of reproductive organs.

Vaginal cytology: After asepsis of the vulva, the vagina was inspected (appearance, shape, color of the vagina and the presence of discharge). Following this process, vaginal smear samples were collected to investigate the estrous cycle. A moistened cotton bud swab was inserted into vagina. The cells from the vaginal lumen and walls were gently taken and transferred to a glass slide. After the samples were allowed to air-dry, it was stained with Giemsa stain and then evaluated under the light microscope. The phases of estrous cycle were classified as proestrus (presence of erythrocytes, gradually increase in cornified cells, decrease in polymorphonuclear leukocyte cells, intermediate and parabasal cells), estrus ( 80 percent of the cells were cornified and anuclear, no polymorphonuclear leukocyte cells), early diestrus (noncornified cells, large number of polymorphonuclear leukocyte cells, epithelial cells engulfing a polymorphonuclear leukocyte cells and the foam cell), late diestrus (primarily polymorphonuclear leukocytes and a few epithelial cells) and anestrus (non-cornified cells and rare polymorphonuclear leukocyte cells) (17).

The histopathological evaluation of ovarian, oviduct and uterine tissues: The samples were removed immediately, and transferred into $10 \%$ neutral formalin solution for fixation. The tissues were put into the cassettes and processed using automated tissue processor 
(Leica, TP1020, Germany), subsequently embedded in paraffin and $4 \mu \mathrm{m}$ thickness sections were obtained for microscopic examination. The slides were stained with Hematoxylin \& Eosin (H \& E). Each H\&E slide was examined blindly under a light microscope (LeicaDM4000, Germany). Microscopically, all samples were classified as proestrus, estrus, diestrus, anestrus according to Sato et al. (21).

Biochemical analyses: The progesterone and thiol/disulphide homeostasis analyses were performed on serum samples, and TAS and TOS levels in reproductive tissues were determined.

Blood specimen collection: Blood samples were collected preoperatively from the vena cephalica antebrachii into plain tubes (Vacutainer ${ }^{\circledR}$ SST ${ }^{\mathrm{TM}}$ II Advance Serum Tubes) for the determination of serum biochemical parameters and kept at $4{ }^{\circ} \mathrm{C}$ for approximately 1 hour. The blood samples were centrifuged at $3000 \mathrm{rpm}$ for $15 \mathrm{~min}$ and sera were stored at $-80^{\circ} \mathrm{C}$ in a freezer until analysis. The progesterone and thiol/disulphide homeostasis levels were analyzed.

The determination of progesterone level: Serum progesterone levels were assayed by Enzyme-Linked Immunosorbent Assay (ELISA; VersaMax ${ }^{\mathrm{TM}}$ ELISA Microplate Reader) using a Canine Progesterone, PROG ELISA kit of Cusabio ${ }^{\circledR}$ and the results were given as $\mathrm{ng} / \mathrm{ml}$. The progesterone data was confirmed with findings of vaginal cytology. Animals with progesterone level 0.5 - $2 \mathrm{ng} / \mathrm{ml}$ were classified as being in proestrus. Animals with progesterone levels $2-15 \mathrm{ng} / \mathrm{ml}$ were classified as being in estrus. Bitches were classified in early diestrus when progesterone levels were above $15 \mathrm{ng} / \mathrm{ml}$. Animals with progesterone levels lower than $10 \mathrm{ng} / \mathrm{ml}$ and higher than $0.5 \mathrm{ng} / \mathrm{ml}$ were classified as being in late diestrus. The bitches with progesterone levels $\leq 0.5 \mathrm{ng} / \mathrm{ml}$ were in anestrus (28).

Serum thiol/disulphide homeostasis: Serum thiol/disulphide homeostasis was identified by newly developed automatic method (10). Dynamic and degradable disulphide bonds $(-\mathrm{S}-\mathrm{S})$ were decreased to free functional thiol groups $(-\mathrm{SH})$ by sodium borohydride $\left(\mathrm{NaBH}_{4}\right)$. Unused reductant sodium borohydride was eliminated with formaldehyde and removed from the environment. All thiol groups including reduced and native thiol were analyzed after reaction with DTNB (5,5'dithiobis-2-nitrobenzoic acid). Native thiol (-SH) and total thiol $(-\mathrm{SH}+-\mathrm{S}-\mathrm{S})$ levels were spectrophotometrically measured. Half of the difference between total thiol and native thiol exhibited the dynamic disulphide amount. Subsequently, total thiol amount, native thiol / total thiol ratio, disulphide / total thiol ratio and disulphide / native thiol ratio were calculated.

Preparation of tissues homogenate: The whole ovarian, oviduct and uterine tissues were homogenized in phosphate saline buffer $(50 \mathrm{mM} ; \mathrm{pH}$ 7.4) and then centrifuged ( $3000 \mathrm{rpm}, 5 \mathrm{~min}, 4^{\circ} \mathrm{C}$ ). The supernatant was separated and used for biochemical analysis.

Measurement of TAS and TOS levels and calculation of OSI: Total antioxidant-oxidant levels in the homogenized ovarian, oviduct and uterine tissues were determined using a novel automated measurement method (Rel Assay kit, Turkey; 8, 9). The antioxidative effect of the sample against the potent free radical reactions, which is initiated by the produced hydroxyl radical, is measured. This assay relies on the ability of antioxidants in the sample to inhibit the formation of 2,2'-azino-bis [3ethylbenz-thiazoline-6-sulfonic acid (ABTS)]. The values of TAS are expressed as mmol Trolox equivalent /L (8).

The colour intensity is related to the total amount of oxidant molecules present in the sample. The test is based on the oxidation of ferrous ion to ferric ion in the presence of various oxidative species in acidic medium and the measurement of the ferric ion by xylenol orange. The assay is calibrated with hydrogen peroxide $\left(\mathrm{H}_{2} \mathrm{O}_{2}\right)$. The results are expressed in terms of $\mu \mathrm{mol} \mathrm{H}_{2} \mathrm{O}_{2}$ equivalent / $\mathrm{L}$ (9).

The OSI was defined as the ratio of the TOS level to TAS level. TAS levels were converted to $\mu \mathrm{mol}$. Specifically, OSI (arbitrary unit) $=$ TOS $\left(\mu \mathrm{mol} \mathrm{H}_{2} \mathrm{O}_{2}\right.$ equivalent/L)/TAS ( $\mu$ mol Trolox equivalent /L) x 100.

Statistical analysis: Statistical analyses were performed by using SPSS 14.01 for Windows (SPSS, Inc., Chicago, IL, USA). Descriptive statistics for each variable were calculated and presented as "Mean \pm Standard Error of Mean". Shapiro Wilk test for normality and Levene test for homogeneity of variances as parametric test assumptions. Kruskal Wallis analysis was used to evaluate the difference between variables and estrous cycle stages. Pearson correlation coefficient and Spearman's rho were used for calculation of the relationship between variables. Statistical significance was assumed at a level of $\mathrm{P}<0.05$.

\section{Results}

The determination of cycle stage: The stages of the estrous cycle were determined using by vaginal cytology, serum progesterone level and histologic findings. According to cytological findings, 9 bitches were in proestrus, 8 in estrus, 10 in diestrus ( 5 in early diestrus, 5 in late diestrus) and 2 in anestrus. These data were confirmed with serum progesterone and histological analysis.

Serum progesterone level: Mean level of progesterone was $1.24 \mathrm{ng} / \mathrm{ml}$ (min: 0.6-max: 1.85) in proestrus, $9.71 \mathrm{ng} / \mathrm{ml}$ (min: 3.88-max: 15.9) in estrus, $14.34 \mathrm{ng} / \mathrm{ml}$ (min: 3.01-max: 30.46) in diestrus (early diestrus $22.85 \mathrm{ng} / \mathrm{ml}$; late diestrus $5.82 \mathrm{ng} / \mathrm{ml}$ ), and 0.39 $\mathrm{ng} / \mathrm{ml}$ (min: 0.30-max: 0.49) in anestrus stages. 
Bright-field microscopy analysis: In proestrus, cortex of the ovary had several antral follicles. The endometrial stroma of the uterine tissue showed oedema and increased luminal crypts and basal glands. In estrus, there were tertiary follicles in ovarian tissue. Granulosa cells were changed to luteal cells. After ovulation, endometrial stromal oedema decreased and number of hypertrophic glands increased. In diestrus, the ovaries had large corpora lutea. Endometrium and myometrium layers exhibited the thickness and cellular density. During anestrus phase, corpora lutea gradually regressed and showed vacuole and had irregular size deeper in the medulla of ovary. The endometrium and myometrium were atrophic and endometrial glands are smaller in the uterus. The oviduct showed ciliated columnar epithelium with equal height secretory cells in proliferative phase. The lower ciliated cells have clear cytoplasm in luteal phase (Figure 1).

TAS, TOS, and OSI values, and correlations: Descriptive analyses of TAS, TOS and OSI values in tissues are shown in Table 1. There was no significant difference $(\mathrm{P}>0.05)$ among TAS, TOS and OSI values in the reproductive tissues in relation to estrous cycle stages (Table 2). Correlation coefficient between variables are shown in Table 3, and between variables and estrous cycle stages are presented in Table 4. Correlation coefficient could not be analysed in anestrus stage due to the inadequate number of samples. Positive correlation was found $(\mathrm{P}<0.05)$ between TOS in the uterine tissue and OSI in the oviduct tissue, and negative correlation was found $(\mathrm{P}<0.05)$ between TAS in the oviduct and TAS in the ovary, TOS in the oviduct and the progesterone, OSI in the oviduct and progesterone, TOS in the uterine tissue and TAS in the oviduct, independently of estrous cycle stages. Positive correlation was found $(\mathrm{P}<0.05)$ between TAS in the oviduct and TOS in the ovarian tissue in estrus stage, TOS in the uterine tissue and TAS in the ovarian tissue in late diestrus stage, and a negative correlation was found $(\mathrm{P}<0.05)$ between TAS in the uterus and progesterone in proestrus stage, TAS in the uterus and TOS in the oviduct in early diestrus stage, TAS in the uterus and OSI in the oviduct in early diestrus stage.

Serum thiol/disulphide homeostasis status: The correlation coefficients between total thiol, native thiol, thiol disulphide and progesterone levels were calculated and positive correlation was found $(\mathrm{P}<0.05)$ between thiol disulphide and total thiol $\left(\mathrm{r}_{\mathrm{p}}=0.950\right)$, progesterone and native thiol $\left(r_{p}=0.603\right)$.
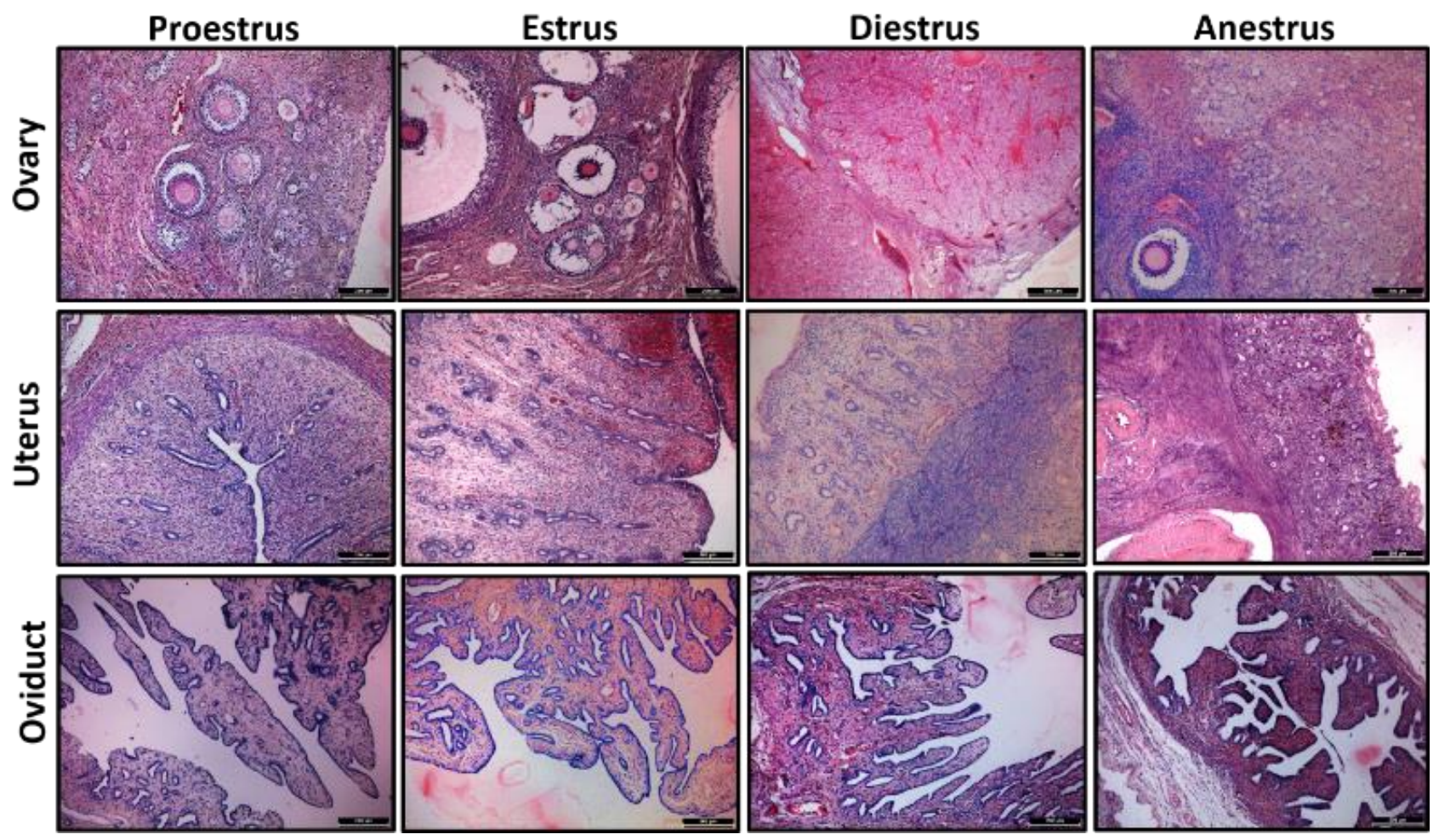

Figure 1. The histological views of ovary, uterus and oviduct tissues in different stages of estrous cycle in bitches. The scale bars: 200 $\mu \mathrm{m}$. 
Table 1. Descriptive statistics for variables.

\begin{tabular}{lcccccc}
\hline Variables & N & Mean & S.E.M & Median & Min & Max \\
\hline Progesterone & 29 & 8.12 & 1.59 & 3.88 & 0.3 & 30.46 \\
TAS Ovary & 29 & 1.15 & 0.08 & 1.06 & 0.46 & 2.04 \\
TOS Ovary & 29 & 9.44 & 1.07 & 8.52 & 1.18 & 22.21 \\
OSI Ovary & 29 & 0.84 & 0.09 & 0.74 & 0.12 & 2.27 \\
TAS Oviduct & 29 & 1.36 & 0.07 & 1.39 & 0.47 & 2.00 \\
TOS Oviduct & 29 & 12.74 & 127 & 10.29 & 3.29 & 25.87 \\
OSI Oviduct & 29 & 1.08 & 0.19 & 0.79 & 0.25 & 5.46 \\
TAS Uterus & 29 & 1.44 & 0.10 & 1.47 & 0.47 & 2.19 \\
TOS Uterus & 29 & 13.98 & 1.23 & 15.07 & 3.23 & 25.92 \\
OSI Uterus & 29 & 1.23 & 0.22 & 0.80 & 0.27 & 5.09 \\
\hline
\end{tabular}

S.E.M: Standard Error of the Mean.

Table 2. The results of differences between variables.

\begin{tabular}{|c|c|c|c|c|c|c|c|}
\hline Variables & Estrous cycle & $\mathbf{n}$ & Mean & S.E.M & Min. & Max. & $\mathbf{P}$ \\
\hline \multirow{4}{*}{ 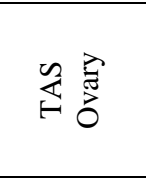 } & Proestrus & 9 & 0.93 & 0.1 & 0.46 & 1.48 & \multirow{4}{*}{0.334} \\
\hline & Estrus & 8 & 1.36 & 0.15 & 0.71 & 2.04 & \\
\hline & Early Diestrus & 5 & 1.14 & 0.26 & 0.62 & 1.91 & \\
\hline & Late Diestrus & 5 & 1.20 & 0.24 & 0.56 & 1.94 & \\
\hline \multirow{4}{*}{ 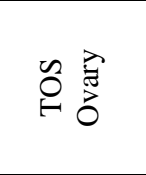 } & Proestrus & 9 & 7.14 & 1.27 & 1.78 & 13.50 & \multirow{4}{*}{0.219} \\
\hline & Estrus & 8 & 12.41 & 1.78 & 5.60 & 18.64 & \\
\hline & Early Diestrus & 5 & 12.22 & 3.39 & 5.89 & 22.21 & \\
\hline & Late Diestrus & 5 & 6.69 & 2.50 & 1.18 & 14.40 & \\
\hline \multirow{4}{*}{$\begin{array}{ll}\vec{E} \\
0 \\
0\end{array}$} & Proestrus & 9 & 0.74 & 0.10 & 0.29 & 1.19 & \multirow{4}{*}{0.262} \\
\hline & Estrus & 8 & 1.04 & 0.23 & 0.4 & 2.27 & \\
\hline & Early Diestrus & 5 & 1.05 & 0.10 & 0.65 & 1.19 & \\
\hline & Late Diestrus & 5 & 0.56 & 0.18 & 0.12 & 1.11 & \\
\hline \multirow{4}{*}{ 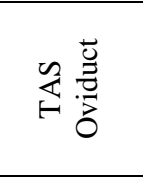 } & Proestrus & 9 & 1.43 & 0.10 & 1.07 & 1.95 & \multirow{4}{*}{0.700} \\
\hline & Estrus & 8 & 1.43 & 0.16 & 0.81 & 2.00 & \\
\hline & Early Diestrus & 5 & 1.28 & 0.17 & 0.64 & 1.59 & \\
\hline & Late Diestrus & 5 & 1.31 & 0.26 & 0.47 & 1.90 & \\
\hline \multirow{4}{*}{ 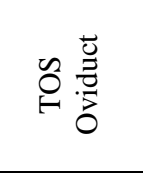 } & Proestrus & 9 & 14.89 & 2.44 & 4.03 & 25.14 & \multirow{4}{*}{0.305} \\
\hline & Estrus & 8 & 9.76 & 1.52 & 4.77 & 18.46 & \\
\hline & Early Diestrus & 5 & 9.65 & 2.39 & 3.69 & 17.21 & \\
\hline & Late Diestrus & 5 & 16.33 & 4.34 & 3.29 & 25.87 & \\
\hline \multirow{4}{*}{$\ddot{\tilde{0}} \cdot \frac{\overline{0}}{0}$} & Proestrus & 9 & 1.04 & 0.17 & 0.29 & 1.78 & \multirow{4}{*}{0.402} \\
\hline & Estrus & 8 & 0.74 & 0.16 & 0.41 & 1.77 & \\
\hline & Early Diestrus & 5 & 0.97 & 0.44 & 0.25 & 2.71 & \\
\hline & Late Diestrus & 5 & 1.76 & 0.94 & 0.34 & 5.46 & \\
\hline \multirow{4}{*}{$\sum_{1}^{\infty}$} & Proestrus & 9 & 1.42 & 0.19 & 0.47 & 2.08 & \multirow{4}{*}{0.23} \\
\hline & Estrus & 8 & 1.31 & 0.19 & 0.55 & 2.12 & \\
\hline & Early Diestrus & 5 & 1.13 & 0.23 & 0.54 & 1.77 & \\
\hline & Late Diestrus & 5 & 1.79 & 0.18 & 1.25 & 2.19 & \\
\hline \multirow{4}{*}{ 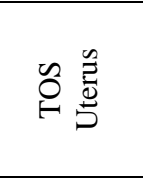 } & Proestrus & 9 & 12.46 & 1.98 & 5.56 & 23.65 & \multirow{4}{*}{0.70} \\
\hline & Estrus & 8 & 14.92 & 2.50 & 4.71 & 23.19 & \\
\hline & Early Diestrus & 5 & 12.64 & 4.45 & 3.23 & 25.92 & \\
\hline & Late Diestrus & 5 & 17.06 & 2.15 & 11.12 & 23.50 & \\
\hline \multirow{4}{*}{ 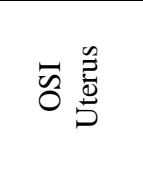 } & Proestrus & 9 & 1.26 & 0.49 & 0.27 & 5.09 & \multirow{4}{*}{0.747} \\
\hline & Estrus & 8 & 1.28 & 0.34 & 0.56 & 3.58 & \\
\hline & Early Diestrus & 5 & 1.50 & 0.84 & 0.34 & 4.84 & \\
\hline & Late Diestrus & 5 & 1.05 & 0.23 & 0.51 & 1.61 & \\
\hline
\end{tabular}

*Difference in anestrus stage could not be analysed in anestrus stage due to the inadequate number of samples. 
Table 3. Correlations between variables.

\begin{tabular}{|c|c|c|c|c|c|c|c|c|c|c|}
\hline & P4 & $\begin{array}{c}\text { TAS } \\
\text { Ovary }\end{array}$ & $\begin{array}{c}\text { TOS } \\
\text { Ovary }\end{array}$ & $\begin{array}{c}\text { OSI } \\
\text { Ovary }\end{array}$ & $\begin{array}{c}\text { TAS } \\
\text { Oviduct }\end{array}$ & $\begin{array}{c}\text { TOS } \\
\text { Oviduct }\end{array}$ & $\begin{array}{c}\text { OSI } \\
\text { Oviduct }\end{array}$ & $\begin{array}{c}\text { TAS } \\
\text { Uterus }\end{array}$ & $\begin{array}{c}\text { TOS } \\
\text { Uterus }\end{array}$ & $\begin{array}{c}\text { OSI } \\
\text { Uterus }\end{array}$ \\
\hline P4 & 1 & & & & & & & & & \\
\hline TAS Ovary & 0.166 & 1 & & & & & & & & \\
\hline TOS Ovary & 0.251 & 0.503* & 1 & & & & & & & \\
\hline OSI Ovary & 0.235 & -0.108 & $0.754 *$ & 1 & & & & & & \\
\hline TAS Oviduct & 0.057 & $-0.426 *$ & 0.035 & 0.289 & 1 & & & & & \\
\hline TOS Oviduct & $-0.395 *$ & 0.006 & -0.080 & -0.149 & 0.035 & 1 & & & & \\
\hline OSI Oviduct & $-0.369 *$ & 0.005 & -0.138 & -0.183 & -0.246 & $0.922 *$ & 1 & & & \\
\hline TAS Uterus & -0.290 & -0.241 & -0.339 & -0.178 & -0.112 & -0.189 & -0.136 & 1 & & \\
\hline TOS Uterus & 0 & 0.233 & 0.210 & 0.083 & $-0.374 *$ & 0.214 & $0.410 *$ & 0.019 & 1 & \\
\hline OSI Uterus & 0.038 & 0.296 & 0.207 & 0.052 & -0.241 & 0.208 & 0.232 & $-0.368^{*}$ & $0.872 *$ & 1 \\
\hline
\end{tabular}

*P $<0.05 ; \mathrm{P} 4$ : Progesterone.

Table 4. Cross correlations for variables according to estrous cycle stages $(n=29)$.

\begin{tabular}{|c|c|c|c|c|c|c|c|c|c|c|c|}
\hline & & P4 & $\begin{array}{c}\text { TAS } \\
\text { Ovary }\end{array}$ & $\begin{array}{c}\text { TOS } \\
\text { Ovary } \\
\end{array}$ & $\begin{array}{c}\text { OSI } \\
\text { Ovary }\end{array}$ & $\begin{array}{c}\text { TAS } \\
\text { Oviduct }\end{array}$ & $\begin{array}{c}\text { TOS } \\
\text { Oviduct }\end{array}$ & $\begin{array}{c}\text { OSI } \\
\text { Oviduct }\end{array}$ & $\begin{array}{c}\text { TAS } \\
\text { Uterus } \\
\end{array}$ & $\begin{array}{c}\text { TOS } \\
\text { Uterus }\end{array}$ & $\begin{array}{c}\text { OSI } \\
\text { Uterus }\end{array}$ \\
\hline \multirow{10}{*}{ 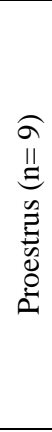 } & $\mathrm{P} 4$ & 1 & & & & & & & & & \\
\hline & TAS Ovary & 0.418 & 1 & & & & & & & & \\
\hline & TOS Ovary & 0.234 & $0.700 *$ & 1 & & & & & & & \\
\hline & OSI Ovary & 0.025 & 0.250 & $0.833^{*}$ & 1 & & & & & & \\
\hline & TAS Oviduct & 0.259 & -0.217 & 0.083 & 0.333 & 1 & & & & & \\
\hline & TOS Oviduct & 0.301 & -0.15 & -0.267 & -0.200 & 0.283 & 1 & & & & \\
\hline & OSI Oviduct & 0.075 & -0.317 & -0.533 & -0.450 & 0.050 & $0.933 *$ & 1 & & & \\
\hline & TAS Uterus & $-0.795^{*}$ & -0.467 & -0.267 & 0 & 0.233 & -0.417 & -0.283 & 1 & & \\
\hline & TOS Uterus & 0.343 & -0.133 & -0.333 & -0.233 & -0.150 & 0.200 & 0.250 & -0.350 & 1 & \\
\hline & OSI Uterus & 0.577 & 0.167 & -0.117 & -0.183 & -0.317 & 0.433 & 0.433 & $-0.783 *$ & $0.783 *$ & 1 \\
\hline \multirow{10}{*}{ 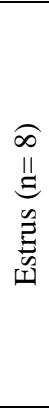 } & $\mathrm{P} 4$ & 1 & & & & & & & & & \\
\hline & TAS Ovary & 0.214 & 1 & & & & & & & & \\
\hline & TOS Ovary & -0.381 & -0.310 & 1 & & & & & & & \\
\hline & OSI Ovary & -0.405 & $-0.714 *$ & $0.833 *$ & 1 & & & & & & \\
\hline & TAS Oviduct & -0.071 & -0.071 & $0.833 *$ & 0.667 & 1 & & & & & \\
\hline & TOS Oviduct & -0.333 & 0.452 & 0.190 & 0.048 & 0.286 & 1 & & & & \\
\hline & OSI Oviduct & -0.262 & 0.190 & -0.476 & -0.381 & -0.619 & 0.500 & 1 & & & \\
\hline & TAS Uterus & 0.024 & -0.119 & -0.619 & -0.214 & -0.500 & -0.071 & 0.238 & 1 & & \\
\hline & TOS Uterus & -0.405 & -0.476 & -0.024 & 0.238 & -0.381 & -0.143 & 0.190 & 0.548 & 1 & \\
\hline & OSI Uterus & -0.500 & -0.119 & 0.333 & 0.286 & -0.024 & 0.190 & 0.071 & 0.167 & $0.810 *$ & 1 \\
\hline \multirow{10}{*}{ 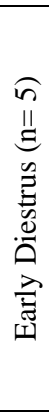 } & $\mathrm{P} 4$ & 1 & & & & & & & & & \\
\hline & TAS Ovary & 0.300 & 1 & & & & & & & & \\
\hline & TOS Ovary & -0.100 & 0.600 & 1 & & & & & & & \\
\hline & OSI Ovary & -0.100 & -0.100 & 0.700 & 1 & & & & & & \\
\hline & TAS Oviduct & -0.100 & -0.600 & -0.200 & 0.300 & 1 & & & & & \\
\hline & TOS Oviduct & 0.600 & 0.100 & 0.300 & 0.500 & -0.300 & 1 & & & & \\
\hline & OSI Oviduct & 0.600 & 0.100 & 0.300 & 0.500 & -0.300 & 1 & 1 & & & \\
\hline & TAS Uterus & -0.700 & -0.300 & -0.500 & -0.600 & 0.100 & $-0.900 *$ & $-0.900^{*}$ & 1 & & \\
\hline & TOS Uterus & -0.200 & 0.700 & 0.500 & -0.100 & $-.900 *$ & 0.100 & 0.100 & 0 & 1 & \\
\hline & OSI Uterus & -0.400 & 0.500 & 0.700 & 0.300 & -0.700 & 0.200 & 0.200 & -0.100 & $.900 *$ & 1 \\
\hline \multirow{10}{*}{ 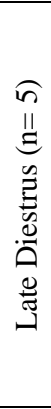 } & $\mathrm{P} 4$ & 1 & & & & & & & & & \\
\hline & TAS Ovary & -0.200 & 1 & & & & & & & & \\
\hline & TOS Ovary & 0.100 & 0.500 & 1 & & & & & & & \\
\hline & OSI Ovary & 0.100 & -0.100 & 0.800 & 1 & & & & & & \\
\hline & TAS Oviduct & -0.500 & -0.700 & -0.400 & 0.100 & 1 & & & & & \\
\hline & TOS Oviduct & -0.500 & 0.300 & 0.600 & 0.600 & 0 & 1 & & & & \\
\hline & OSI Oviduct & -0.500 & 0.300 & 0.600 & 0.600 & 0 & 1 & 1 & & & \\
\hline & TAS Uterus & 0.700 & -0.700 & 0.100 & 0.500 & 0.200 & -0.300 & -0.300 & 1 & & \\
\hline & TOS Uterus & -0.500 & $0.900 *$ & 0.300 & -0.200 & -0.500 & 0.500 & 0.500 & $-0.900 *$ & 1 & \\
\hline & OSI Uterus & -0.700 & 0.700 & -0.100 & -0.500 & -0.200 & 0.300 & 0.300 & -1 & 0.900* & 1 \\
\hline
\end{tabular}

$* \mathrm{P}<0.05$; P4: Progesterone. Correlation coefficient could not be analysed in anestrus stage due to the inadequate number of samples $(\mathrm{n}=2)$. 


\section{Discussion and Conclusion}

The estrous cycle of bitches is classically divided into 4 recurring stages: proestrus, estrus, diestrus, and anestrus. These stages reflect the change of steroid hormone, and LH surge. Estrogen levels rise in follicular stage, progesterone levels increase with preovulator luteinisation in the initial stage of luteal period following LH surge, estrogen levels decrease immediately, ovulation occurs, progesterone declines slowly after 20-35 days of cycle, thereafter going below $1 \mathrm{ng} / \mathrm{ml}$, respectively $(5,17)$. The determination of estrous cycle in dog breeding has a crucial role because of monoestrus pattern. Therefore, many diagnostic methods are developed for the detection of estrous cycle in dogs. For this purpose, progesterone and LH assay, vaginoscopy, vaginal cytology, behavioural and physical changes, ultrasonographic view of ovaries, electrical impedance of vagina, glucose concentration in vaginal fluid, ferning of vaginal fluid $(11,16,28)$ and histological evaluation of reproductive tissues (21) are used. However, vaginoscopy, vaginal cytology and progesterone analysis are mostly preferred in clinical practice (3). In the present study, the stages of estrous cycle were characterized by vaginal cytology and serum progesterone level. Also, these results were confirmed with bright microscopic view of ovarian, oviduct and uterine tissues. Histological data were verified by our findings of vaginal cytology and progesterone analysis.

The estrogen concentration increases in progressive process, and accordingly oxidative balance shows an alteration due to antioxidative effect of estrogen $(7,26$, 27). With the development of follicles, an increase in antioxidant substances is observed in the follicular fluid. Thus, granulosa cells, oocytes and steroidogenesis process are preserved. However, the ROS concentration begins to increase following preovulatory LH surge in the estrus stage. It is known that severe lipid peroxidation occurs in the preovulatory graafian follicle. Increased PMN and leucocytes, which are a part of the process of acute inflammation, due to LH peak during ovulation lead to increased ROS concentration $(1,20,23)$. The result of TAS, TOS and OSI in different reproductive tissues in our study revealed that some variations about oxidative stress parameters were going on in the ovary, oviduct and uterine tissue concurrently. In the proestrus stage, uterine TAS and progesterone were negatively correlating, and TAS level in the oviduct tissue was positively correlating with TOS in the ovarian tissue. After all, TAS level in the uterus had a negative correlation with oviduct tissue TOS and OSI level in early diestrus stage. These findings suggested that oviduct was prepared with elevated TAS level to prevent oocyte after ovulation while ovary was in the periovulator/ovulator period with increased TOS level in estrus stage. The uterine antioxidant status was negatively affected while oxidative stress was being in raised in the oviduct tissue during early diestrus stage probably due to increased steroidogenesis and progesterone synthesis. Because, ROS plays a role as both a by-product and an influencer in progesterone synthesis in this period. In relation with thiol/disulphide homeostasis, there was a relationship between native thiol and progesterone levels in the present study. According to this finding, it was though that there might be an antioxidative protection mechanism with elevated native thiol level, synchronously with increased progesterone concentration during estrus and early diestrus stage.

In conclusion, the physiological values of TAS and TOS concentration, and OSI in the ovarian, oviduct and uterine tissues during estrous cycle were firstly defined in this article. The serum thiol/disulphide homeostasis was also determined in the estrous cycle of bitches. We have found that there is a remarkable variations of oxidative stress balance in the ovary, oviduct and uterus concurrently, during estrous cycle in the bitches. Besides, significant correlations between oxidative stress parameters and estrous cycle stages in the reproductive tissues were observed in the present study. According to results of present study, it was thought that follicular structure and fertility could be affected by oxidant/antioxidant profile changes in reproductive tissues. It was concluded that further studies should be conducted on this issue in dogs and other animal species.

\section{Acknowledgement}

This study was supported by Scientific Research Projects Coordination Unit of Afyon Kocatepe University (Project No: 18.KARIYER.127).

\section{Conflict of Interest}

The authors declared that there is no conflict of interest.

\section{References}

1. Agarwal A, Gupta S, Sharma RK (2005): Role of oxidative stress in female reproduction. Reprod Biol Endocrinol, 3, 28.

2. Alaçam E, Ay SS, Saban E (2009): Inek, koyun ve köpeklerde değişik radioimmunoassay progesterone ölçüm kitlerinin reprodüktif sürecin farkl evrelerinde değerlendirilmesi. Ankara Univ Vet Fak Derg, 56, 37-41.

3. Bladowska K, Baranski W, Janowski TE (2018): Preovulatory progesterone secretion terminates the duration of reproductive behavior during heat in the bitch. Pol J Vet Sci, 21, 615-622.

4. Circu ML, Aw TY (2010): Reactive oxygen species, cellular redox systems, and apoptosis. Free Radic Biol Med, 48, 749-62. 
5. Concannon PW (2011): Reproductive cycles of the domestic bitch. Anim Reprod Sci, 124, 200-210.

6. Çamkerten İ, Çamkerten G, Erdoğan H, et al (2019): Serum thiol disulphide levels among sheep with sarcoptic mange. Kafkas Univ Vet Fak Derg, 25, 865-868.

7. Delgobo M, Agnes JP, Gonçalves RM, et al (2019): $N$ acetylcysteine and alpha-lipoic acid improve antioxidant defenses and decrease oxidative stress, inflammation and serum lipid levels in ovariectomized rats via estrogenindependent mechanisms. J Nutr Biochem, 67, 190-200.

8. Erel O (2004): A novel automated direct measurement method for total antioxidant capacity using a new generation, more stable ABTS radical cation. Clin Biochem, 37, 277-285.

9. Erel O (2005): A new automated colorimetric method for measuring total oxidant status. Clin Biochem, 38, 11031111.

10. Erel O, Neselioglu S (2014): A novel and automated assay for thiol/disulphide homeostasis. Clin Biochem, 47, 326332.

11. Hollinshead FK, Hanlon DW (2019): Normal progesterone profiles during estrus in the bitch: A prospective analysis of 1420 estrous cycles. Theriogenology, 125, 37-42.

12. Hossein MS, Kim MK, Jang G, et al (2007): Effects of thiol compounds on in vitro maturation of canine oocytes collected from different reproductive stages. Mol Reprod Dev, 74, 1213-1220.

13. Lázár L (2012): The Role of Oxidative Stress in Female Reproduction and Pregnancy, Oxidative Stress and Diseases. InTech Europe.

14. Lu J, Wang Z, Cao J, et al (2018): A novel and compact review on the role of oxidative stress in female reproduction. Reprod Biol Endocrinol, 16: 80.

15. Pech LGM, Caballero-Chacon SDC, Guarner-Lans V, et al (2019): Effect of oophorosalpingohysterectomy on serum antioxidant enzymes in female dogs. Sci Rep, 9: 9674.

16. Root Kustritz MV (2010): How Do I Use Progesterone and Other Measures for Breeding Management? 97-100. In: MV Root Kustritz (Ed), Clinical Canine and Feline Reproduction: Evidence-Based Answers. Wiley-Blackwell Publishing, Iowa.
17. Root Kustritz MV (2012): Managing the reproductive cycle in the bitch. Vet Clin North Am Small Anim Pract, 42, 423-437.

18. Rizzo A, Roscino MA, Minoia G, et al (2009): Serum levels of reactive oxygen species (ROS) in the bitch. Immunopharmacol Immunotoxicol, 31, 310-313.

19. Rizzo A, Minoia G, Trisolini C, et al (2009): Reactive oxygen species (ROS): involvement in bovine follicular cysts etiopathogenesis. Immunopharmacol Immunotoxicol, 31, 631-635.

20. Rizzo A, Roscino MT, Binetti F, et al (2012): Roles of reactive oxygen species in female reproduction. Reprod Dom Anim, 47, 344-352.

21. Sato J, Nasu M, Tsuchitani M (2016): Comparative histopathology of the estrous or menstrual cycle in laboratory animals. J Toxicol Pathol, 29, 155-162.

22. Senger PL (2005): Reproductive Cyclicity - Terminology and Basic Concepts 144-163. In: Senger PL (Ed), Pathways to Pregnancy and Parturition. Current Conception, Inc. Washington.

23. Shkolnik K, Tadmor A, Ben-Dor S, Nevo N, Galiani D, Dekel N (2011): Reactive oxygen species are indispensable in ovulation. Proc Natl Acad Sci USA, 108, 1462-1467.

24. Sugino N (2006): Roles of reactive oxygen species in the corpus luteum. Anim Sci J, 77, 556-565.

25. Takahashi M, Nagai T, Hamano S, et al (1993): Effect of thiol compound on in vitro development and intracellular glutathione content of bovine embryos. Biol Reprod, 49, 228-232.

26. Tropea A, Miceli F, Minici F, et al (2006): Regulation of vascular endothelial growth factor synthesis and release by human luteal cells in vitro. J Clin Endocrinol Metab, 91, 2303-2309.

27. Unfer TC, Figueiredo CG, Zanchi MM, et al (2015): Estrogen plus progestin increase superoxide dismutase and total antioxidant capacity in postmenopausal women. Climacteric, 18, 379-388.

28. Van Cruchten S, Van den Broeck W, D'haeseleer M, et al (2004): Proliferation patterns in the canine endometrium during the estrous cycle. Theriogenology, 62, 631-641. 